\title{
Numerical Simulation of Spark-kernel Formation by Breakdown and Glow Discharge
}

$\begin{array}{rlll}\text { O学 小平 } & \text { 壽美子 } & \text { (京大院) } \\ \text { 正 塩路 } & \text { 昌宏 } & \text { (京都大) }\end{array}$

Sumiko KOHIRA, Graduate School of Kyoto University, Yoshida Honmachi, Sakyo-ku, Kyoto Hiroshi KAWANABE, Kyoto University

Masahiro SHIOJI, Kyoto University

\begin{abstract}
Numerical simulation of the spark-kernel formation by breakdown and glow phase of discharge was carried out. In order to describe the shock wave caused by local high temperature and pressure due to breakdown discharge, the compressive transport equations of mass, momentum, energy and concentration were calculated. The detail profiles of temperature and pressure were investigated in the early stage of the spark-kernel. The results show that the effects of diameter and duration of discharge on the minimum ignition energy are clarified in the case of using the breakdown discharge. Furthermore, the process of ignition by the composition discharge with breakdown and glow phase was revealed.
\end{abstract}

Keyword: Gasoline Engine, Ignition, Premixed Combustion, CFD, Discharge

\section{1. まえがき}

火花点火過程は内燃機関における燃焼変動などに大きく 影響を与えるために，その過程の詳細を把握することは重 要であり, 現在までに数多くの実験および数值解析が行わ れている(1). 通常, 火花点火式内燃機関に用いられる点火回 路の放電過程の特徴は, 予混合気中における直径 $40 \mu \mathrm{m}$ 程 度の細い円筒状の経路に 10 ns 以下の非常に短い時間でエ ネルギーの加わるいわゆる容量放電と, 直径 $1 \mathrm{~mm}$ 程度で 数 $\mathrm{ms}$ にわたる誘導放電の組み合わせとなることである(2). とくに，容量放電による点火現象は短時間でかつ狭い領域 で瞬間的に発生する高温・高圧によって衝撃波が生じ，そ の後の燃焼過程に大きく影響を与える。しかし，実験的に この現象を捉えるのは困難であり，さらに，数值解析を行 うためには衝撃波を捉える詳細な数值計算コードが必要で ある。このため，容量放電による点火過程については不明 な点が多い.

そこで本研究では, 既報(3)で提案した数值計算モデルに基 づいて容量·誘導放電による点火過程を詳細に検討する。こ れは，圧縮性を考慮したナビエストークス方程式を用いて 解析を行うもので，これにより容量放電のみを用いた場合 の種々の条件における点火過程を計算するとともに種々の 点火条件が最小点火エネルギーに及ぼす影響を調べる。さ らに, 容量放電に誘導放電が加わった際の点火過程につい て検討する。

\section{2. 計算モデル}

\section{1 流動計算および対象}

容量放電により発生する衝撃波を扱うために，圧縮性を 考慮した非定常のナビエストークス方程式を連続の式およ びエネルギー保存式と併せて解く．数值計算は差分法で行 い, 空間の離散化には 2 次の中心差分, 時間進行積分には 有理ルンゲクッ夕法(4)を用いる。

計算対象は図 1 に际ような 2 電極間に生じる直径 $d$ の 円筒状の放電経路を考え，そこに存在する予混合気にエネ ルギーが与えられて燃焼が開始する過程を扱う。計算は軸 対称 1 次元を仮定するとともに，その半径方向の座標を $r$,
計算格子の大きさは $5 \mu \mathrm{m}$ とする.時間ステップはクーラン 数が 1 を超えないように計算ステップ毎に定める.

2.2 火花放電および然焼モデル

放電経路中に一様のエネルギーを加えることによって火 花放電を表す。すなわち，容量放電では，放電期間中に一 定のエネルギーを保存式の生成項に加え, 誘導放電では時 間とともに比例して減少するエネルギー加える。燃料はガ ソリンを仮定し， $\mathrm{H} / \mathrm{C}=1.75$ の炭化水素とするとともに， その反応速度は燃料のモル濃度 $C_{f}$ の減少速度として式 (1) のようなアレニウス型の 1 段総括反応で表す(5). また, 発熱 量に見合ったエネルギーを保存式の生成項に加える。

$$
\frac{d C_{f}}{d t}=-A T p^{0.3} C_{f}^{0.5} C_{o} \exp \left(\frac{T_{a}}{T}\right)
$$

ただし， $C$ は酸素のモル濃度， $A$ および $T$ は頻度因子お よび活性化温度であり，それぞれ $7.3 \times 10^{5}$ および $12.2 \times 10^{3}$ とする。ここでは, 完全燃焼を仮定し燃焼生成物の定圧比 熱は 6 次の多項式で表すとともに, $7000 \mathrm{~K}$ 以上では 7000 $\mathrm{K} に$ におる值で一定とした。これらの值を用いて1次元層 流火炎の数值計算を行った結果, $300 \mathrm{~K}, 0.1 \mathrm{MPa}$ における 燃焼速度が当量比 $\phi=1$ において $0.34 \mathrm{~m} / \mathrm{s}, \phi=0.85$ では

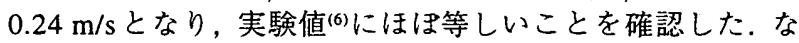
お，本計算では電極への熱損失は考慮していない。

\section{3. 計算結果}

はじめに,容量放電における点火過程を数值計算する。図 2 は当量比 $\phi=1$ について放電直径 $d=0.2 \mathrm{~mm}$, 期間 $t_{i}=10$

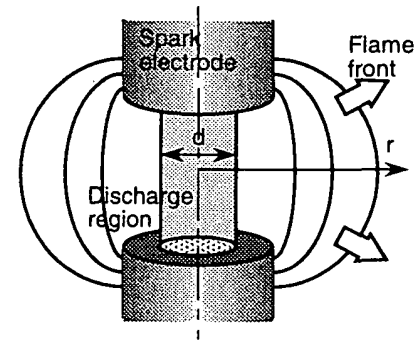

Fig. 1 Schematic of ignition process 

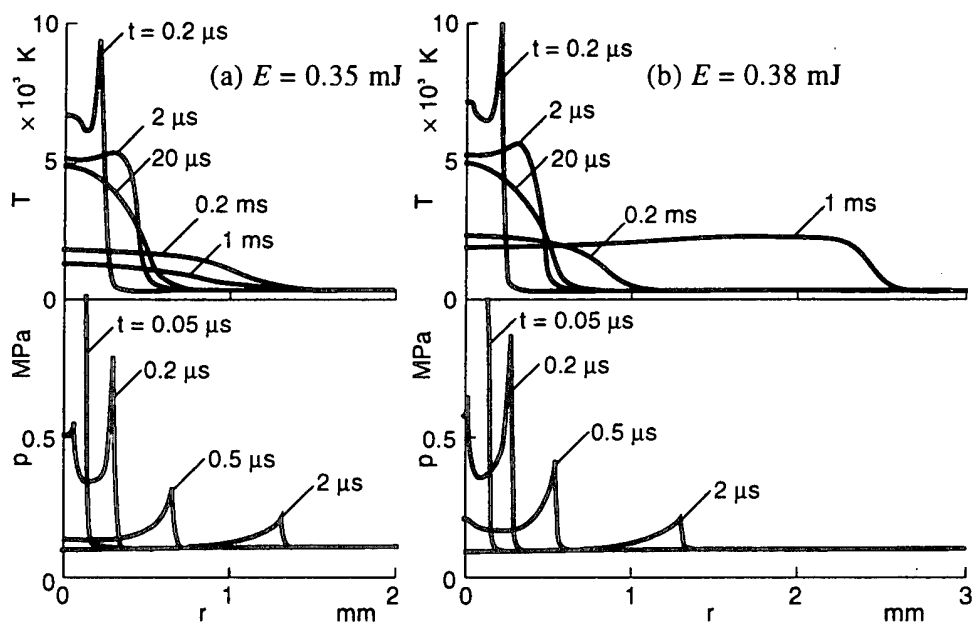

Fig. 2 Radial profiles of temperature $T$ and pressure $p$ in ignition process $\left(\phi=1.0, d=0.2 \mathrm{~mm}, t_{i}=10 \mathrm{~ns}\right)$

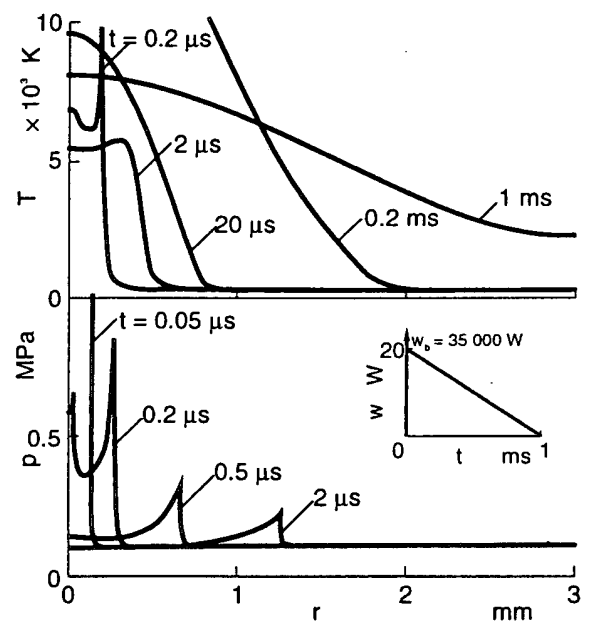

Fig. 6 Radial profiles of temperature $T$ and pressure $p$ in ignition process (with glow discharge)
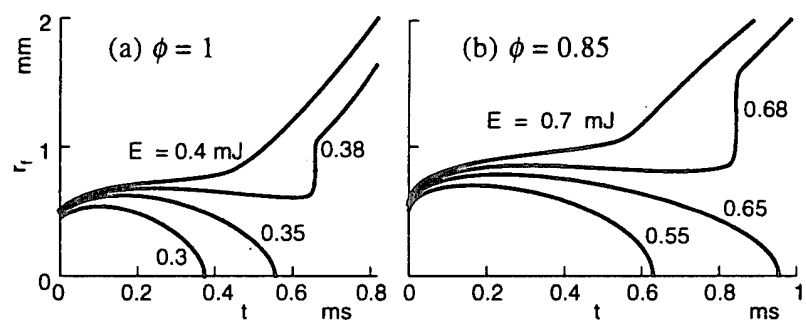

Fig. 3 Course of radius $r_{f}$ where $T$ is $1800 \mathrm{~K}$ $\left(d=0.2 \mathrm{~mm}, t_{i}=10 \mathrm{~ns}\right)$

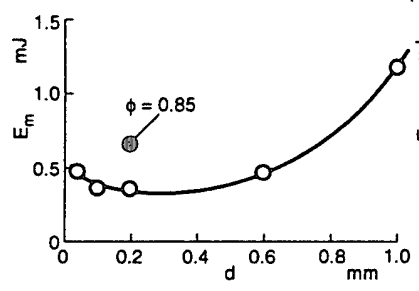

Fig. 4 Effect of $d$ on $E_{\text {m }}$ $\left(\phi=1, t_{i}=10 \mathrm{~ns}\right)$

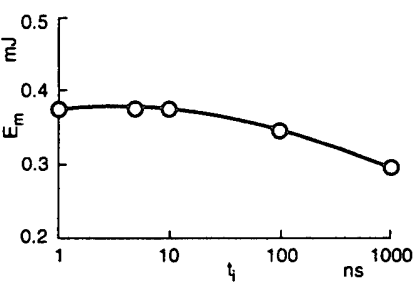

Fig. 5 Effect of $t_{i}$ on $E_{m}$ $(\phi=1, d=0.2 \mathrm{~mm})$ $\mathrm{ns}$ とし，点火エネルギーEを (a) $0.35 \mathrm{~mJ}$ と (b) $0.38 \mathrm{~mJ}$ と した際の温度および圧力の $r$ 方向分布の時間変化を示す.こ れによると, (a) では点火の瞬間は中心付近の温度が 10000 $\mathrm{K}$ 程度にまで上昇するが，その後急激に減少し，1 msでは $2000 \mathrm{~K}$ 以下となって，火炎が伝播しない。これに対して， (b) では点火の瞬間は (a) と同様に中心付近の温度は 10000 Kまで上昇したのち $0.2 \mathrm{~ms} て ゙ は ~ 3000 \mathrm{~K}$ まで下がるが，そ の後，然焼反応に伴って $2000 \mathrm{~K}$ 以上の領域が外に向かっ て拡がっており，着火していることが判る。また，圧力波 は(a) (b) いずれの場合も火炎の伝播よりもはるかに速く外 側に伝わっていく様子が計算されている.

つぎに, T>1800 K となる領域の半径 $r$ の増減によって 着火および失火の判定を行う. 図 3 は量論比となる (a) $\phi=$ 1 および希薄条件の (b) $\phi=0.85$ について $d=0.2, t_{i}=10 \mathrm{~ns}$ とした際の種々の点火エネルギーにおける $r_{f}$ の時間変化を 示す. (a)について $0.38 \mathrm{~mJ}$ では $r$ が $0.65 \mathrm{~ms}$ で急激に増大 するのに対して, $0.35 \mathrm{~mJ}$ では隇少し， $0.55 \mathrm{~ms}$ において 1 $800 \mathrm{~K}$ 以上になる領域が無くなることがわかる.このことか ら最小点火エネルギーは $0.35 \mathrm{~mJ}$ と $0.38 \mathrm{~mJ}$ の間に存在す ると考えられる.さらに，(b)では $0.68 \mathrm{~mJ}$ で着火するのに
対して $0.65 \mathrm{~mJ}$ では $0.95 \mathrm{~ms}$ で $r$ が 0 となっており，量論 条件に比べて大きな点火エネルギーが必要なことがわかる. 以上のような計算を行い, 着火する場合と失火する場合の 平均エネルギーを求めれば $5 \%$ 程度の誤差の範囲で最小点 火エネルギーを推定することができる。本手法を用いて,放 電の直径 $d$ および期間 $t_{i}$ が最小点火エネルギーに及ほす影 響を調べる. 図 4 は $t_{i}=10 \mathrm{~ns}$ 一定として, $d$ を変化した際

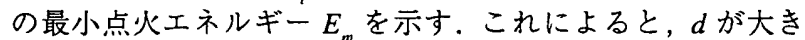
いほど $E_{m}$ が大きくなり,放電領域のエネルギー密度が下が ると失火しやすくなる. 逆に $d$ が $0.1 \mathrm{~mm}$ 以下と小さくな るとエネルギーの拡散が速くなり $E_{m}$ が大きくなる。図 5 は $d=0.2 \mathrm{~mm}$ としたときに $t_{i}$ に対する $E_{m}$ の変化であり, $t_{i}$ が 大きくなれば $E_{m}$ が小さくなる.これは，図 4 の結果と同様 に短時間でエネルギーを与えるとその拡散が速いためであ る、ただし，本計算では電極への熱損失を考慮していない ため実験值に比べて小さな最小点火エネルギーが得られて いるが，定性的には傾向を記述できている。

最後に, 容量放電に誘導放電を加えた際の点火過程を計 算する.ここでは図 2 (a) の容量放電条件に誘導放電として $10 \mathrm{~mJ}$ のエネルギーを時間に比例して隇少するように $1 \mathrm{~ms}$ の期間 $d=1 \mathrm{~mm}$ の領域に加える. 図 6 はその結果であり, $2 \mu \mathrm{s}$ までは図 2 (a) とほほ同様であるが，その後は誘導放 電によって高温部が広い領域で生じるとともに，着火に至 ることがわかる.

\section{4.まとめ}

以上，圧縮性を考慮した流動計算コードを用いて，容量・ 誘導放電による点火過程の数値解析を行った.その結果, 容 量成分のみを与えた場合の着火に至る様子を示すとともに， 最小点火エネルギーに及ほす放電直径・期間の影響につい て検討した。さらに，誘導放電を付加することによって広 い領域で高温部が生じ, 着火に至ることが明らかになった。

おわりに，研究の遂行にご協力いただいたトヨ夕自動車 (株) 山田 敏生 氏に感謝いたします。

\section{参考文献}

(1) 例えば, Lewis, B. and Elbe, G. Von, 2nd ed. Academic Press (1961), 323 346. (2) Heywood, J. B., Internal Combustion Engine Fundamentals (1988), 427. 437, McGrraw-Hill, Inc. (3) 山田・塩路・池上，第 36 回燃焼シンボジウム (1998), 240-242. (4) Satofuka, N., Proc. 5th Gamm Gonf. Numerical Methods Fluid Mech (1983), 291-298. (5) Edelman, R. B. and Harsha, P. T., Energy Combustion Science, Vol. 4 (1978), 1-62.(6) Heywood, J. B., Internal Combustion Engine Fundamentals (1988), 403, McGrraw-Hill, Inc. 